the Upper Cretaceous of Alberta, Canada, are also described in several papers by Mr. Barnum Brown, who discusses chiefly the Trachodontidæ (related to Iguanodon) and the horned dinosaurs or Ceratopsia. Among other observations he makes specially valuable notes on the brain-cavities of these two groups. It appears that just before their extinction the dinosaurs in North America exhibited almost incredible variety and eccentricity.

When the first Tertiary mammals were discovered in North America, too little attention was paid to the geology of the deposits whence they were obtained. The American Museum has, always recognised this deficiency, and the new collection of papers includes some valuable contributions to our knowledge of the lowest Tertiary formations. Of the mammals themselves, Prof. H. F. Osborn describes the skull of Bathyopsis, a supposed ancestor of the Dinocerata, and a skull with other remains of Eomoropus, a new genus ancestral to the anomalous hoofed animals known as Chalicotheriidx. Dr. W. J. Sinclair gives technical descriptions of the rare pieces of jaws of pig-like artiodactyls from the Eocene of North America, and Dr. R. W. Shufeldt discusses many fragmentary remains of birds. Dr. W. D. Matthew also describes the important discovery in the lowest Eocene of New Mexico of the skull of an insectivore related both to the existing Chrysochloris of South Africa and to the extinct Necrolestes of South America, thus proving that the close affinities of these two genera do not imply any former direct connection between the two southern continents in which they occur. All the papers are well illustrated with text-figures and plates, and the American Museum is to be congratulated on the manner as well as the matter of its publications.

A. S. W.

\section{STUDIES OF HYMENOPTERA.}

SOME small hymenopterous parasites of the notorious Hessian fly form the subject of a paper by C. M. Packard in the Journal of Agricultural Research, vi., No. ro. The life-histories of three species belonging to the genera Eupelmus, Merisus, and Micromelus are described, and the figures of eggs, larvæ, and pupæ are especially valuable. The author concludes that never more than a single individual of either of these parasites can mature in a single cecid puparium. Where more than one egg was placed on the same host, one larva onily survived; "the rest were killed by that one or starved to death ... whether the "two or more larvæ were of the same or different species."

It is well known that certain species of the Chalcididæ -small Hymenoptera that are typically parasitic in their habits-lay their eggs in plant tissues on which their larvæ feed, and the genus Megastigmus has been noticed as injurious to fir seeds. J. M. Miller (Journ. Agric. Research, vi., No. 2) is the first to describe the actual operation of egg-laying by these minute flies; the female pierces the scales of the young cones with her long ovipositor and lays the eggs close to the developing seeds. The process is well illustrated by Mr. Miller's photographs.

The literature of the honey-bee is ever increasing. A noteworthy paper on the sense-organs on the mouthparts of the bee is published by Dr. N. E. McIndoo in the Smithsonian Misc. Collections (lxv., No, I4); he gives the results of experiments by feeding bees on various substances, and describes with clear figures the minute structure of the sense-organs under discussion. When "undesirable substances" were added to the bees' food, the insects were found to refuse such "after eating more or less of them," and the author concludes that "the olfactory sense in the honey-bee

NO. 2457 , VOL. 98$]$ is highly developed, and that it serves as an olfactory and gustatory perception combined."

Systematic work on the ants claims the attention of entomologists in distant regions. In the Ann. South African Museum (xiv., part 2), G. Arnold continues his extensive "Monograph of the Formicidæ of South Africa." A. Gallardo publishes a monograph of the Dolichoderinæ as a contribution to "Las Hormigas de la República Argentina," in the Ann. Mus. Nat. de Hist. Nat. de Buenos Aires (xxviii., 1916, pp. I-130), a praiseworthy feature of which is the addition of at least one clear structural figure to the description of each species. The Argentine ant, Iridomyrmex humilis, is discussed at length, the description of its varieties and habits occupying sixteen pages. This insect has in recent years become a serious pest in parts of the United States; colonies have also been introduced into southern Europe, and some time ago these ants gained a temporary footing in a garden near Belfast, whence they invaded the adjacent dwelling-house, with the result of considerable alarm and inconvenience to the inhabitants.

G. H. C.

OBSERVATIONS ON RECENTLY DISCOVERED FOSSIL HUMAN SKULLS. 1 I HE announcements made in NATURE last year (1915, August 5, p. 615; September 9, discovery of fossil human skulls in Australia (Talgai) and South Africa (Boskop) suggest certain observations concerning the problems relating to early mankind. For not only do they add to the number of the distinct types of early humanity with which we are acquainted, but they also force upon us the further consideration of the question of early migrations, of the reality of which the widespread distribution of certain definite types of stone implements already afforded convinoing testimony for all who were willing to accept the plain significance of positive evidence.

There are reasons for believing that when Homo sapiens first became differentiated from other human species many human strains other than those which made their way into western Europe in the Upper Palæolithic (which may be called the Early Neoanthropic, see Nature, August I7, I916, p. 514) age were also budded off from the original parent stock. Some of these diversely specialised strains were the ancestors of the Australians, others of negroes, others again of the Mongolian race, and yet others of the brachycephalic types of humanity, none of which were represented in Europe, excepting possibly the last of the groups mentioned, which began to filter into eastern Europe in Azilian times, but did not become at all common in the West until the closing phases of the Neolithic. 'Some of these various strains wandered far from their area of characterisation; and when brought into contact with other stocks were able to transmit their culture. Thus it is possible to explain how, even in the remote period usually called Palæolithic, identical methods of chipping stone implements in widely separated localities can be regarded as certain evidence of the derivation of the technique from a common source, though the actual makers of the weapons may be of different races. Nor can the source of the inspiration be in doubt even if certain peoples may continue to follow the distinctive methods in the twentieth century.

Further, a particular culture-complex may have been built up of practices and customs derived from varied sources: the particular set of them which becomes intermingled in one area, and the type of culture which develops as the result of the blending of these in-

I Abstract of a paper read before he Manchester Literary and Philo. sophical Society on October 31 by Prof. G Elliot Smith, F.R.S. 